\title{
Teologia das religiões em perspectiva protestante
}

\author{
Alonso Gonçalves*
}

\begin{abstract}
RESUMO
$\mathrm{O}$ artigo tem como preocupação a temática da Teologia das Religiões a partir da perspectiva protestante como uma contribuição do debate para o contexto latino-americano. A abordagem se faz necessária, quando há uma constatação de uma quase ausência do tema na reflexão teológica protestante na América Latina, havendo, por outro lado, o desenvolvimento da temática por teólogos e teólogas católicas com um certo dinamismo e produção acadêmica de qualidade. Ainda que o protestantismo tenha contribuído para a reflexão teológica das religiões, constatamos uma maior disseminação do conteúdo teológico de autores que forneceram caminhos para se pensar uma Teologia das Religiões que tenha como ponto de partida a tradição protestante. É nesse sentido que esse artigo se faz pertinente, quando procura fornecer alguns temas trabalhados por teólogos protestantes visando uma melhor aproximação teológica e dialógica com as demais tradições religiosas.

Palavras-chave: Teologia das Religiões. Teologia Protestante. Diálogo Inter-religioso.
\end{abstract}

\section{Theology of religions in protesting perspective}

\begin{abstract}
The article is concerned with the theme of theology of religions from the Protestant perspective as a contribution of the debate to the Latin American context. The approach is necessary when there is a near absence of the theme in Protestant theological reflection in Latin America, and there is, on the other hand, the development of the theme by Catholic theologians and with a certain dynamism and quality academic production. Although Protestantism contributed to the theological reflection of
\end{abstract}

* Doutor em Ciências da Religião pela Universidade Metodista de São Paulo. Contato: <alonso3134@hotmail.com>. Lattes:<http://lattes.cnpq.br/1066881650609101>. 
religions, we found a greater dissemination of the theological content of authors who provided ways to think about a Theology of Religions that has as its starting point the Protestant tradition. It is in this sense that this article becomes pertinent, when it seeks to provide some themes worked by Protestant theologians aiming at a better theological and dialogical approach with the other religious traditions.

Keywords: Theology of Religions. Protestant theology. Interreligious Dialogue.

\section{Introdução}

O tema das religiões ganha contornos com diferentes autores, que procuram fazer abordagens tendo como foco o pluralismo religioso e o diálogo inter-religioso a partir da América Latina. A constatação da pluralidade religiosa provocou a reflexão teológica, mais ainda em ambiente católico, mas também, em menor proporção, em ambiente protestante. O tema do pluralismo movimentou a teologia que, diante das demais tradições religiosas, procurou/procura refletir e dialogar. Tanto a teologia católica quanto a teologia protestante, se viram diante de um desafio: procurar entender esse pluralismo de fato, de princípio, de direito e, como consequência, tecer caminhos que possibilitem o diálogo inter-religioso, dentro de suas respectivas tradições, preservando, assim, os principais elementos constitutivos da teologia denominada cristã. É diante dessa realidade que, tanto católicos quanto protestantes, aceitaram o desafio, notadamente mais os primeiros e, ainda timidamente, os segundos. Assim, procurou-se uma melhor adequação, em termos de posições teológicas, diante da realidade inconteste das religiões e suas tradições, ritos, doutrinas, moralidade e ética. Com isso, uma primeira e discutível tentativa de classificação das posturas teológicas diante do desafio de compreender as religiões, se deu a partir de três perspectivas: exclusivismo (só há uma religião verdadeira), inclusivismo (as demais religiões, de alguma maneira, são caminhos, mas enquanto apontam para o cristianismo) e pluralismo (a salvação não é exclusividade apenas do cristianismo). O autor que procura trabalhar com essas categorias é Faustino Teixeira. No seu texto, Teologia e pluralismo religioso (2012), Teixeira faz uma análise dos principais autores comprometidos com cada uma dessas categorias, dentre eles dois 
protestantes, Karl Barth - o qual Teixeira o qualifica, acertadamente, como exclusivista - e Paul Tillich, o qual o autor tem dificuldades em colocá-lo em uma das categorias: "Não é fácil enquadrar a reflexão de Tillich sobre as religiões entre os tradicionais paradigmas existentes" (TEIXEIRA, 2012, p. 53). Já, o também teólogo católico Paul F. Knitter, prefere nomear as distinções teológicas diante do pluralismo religioso como "modelos". No seu texto, Introdução às teologias das religiões (2008), Knitter classifica as posições teológicas diante do pluralismo religioso como: modelo de substituição (somente uma religião verdadeira); modelo de complementação (o Um dá completude aos vários); modelo de mutualidade (várias religiões, em diálogo); modelo de aceitação (várias religiões verdadeiras). Esses dois textos, demonstram as dificuldades em categorizar e tematizar a pluralidade religiosa, mesmo a partir de um enquadramento cristão. Isso já demonstra a amplitude do tema, bem como também a necessidade em apontar outras vertentes de reflexão. Ainda que as categorias sejam diversas, há um consenso de que a pluralidade religiosa convoca e provoca à teologia a refletir sobre a questão do pluralismo religioso:

A teologia das religiões se tornou um dos capítulos mais vivos da teologia contemporânea. Somos tentados a dizer que, assim como o ateísmo e a secularização foram o horizonte em função do qual a teologia da segunda metade do século XX reinterpreta as grandes verdades da fé cristã, o pluralismo religioso tende a vir a ser o horizonte da teologia do século XXI e ele nos convida a revisitar os grandes capítulos de toda a dogmática cristã (GEFFRÉ, 2013, p. 43).

A discussão em torno do tema - teologia e sua relação com as religiões - tem sido profícua e necessária em tempos de cultura globalizada e, ao mesmo tempo, fragmentária. Além disso, a teologia tem como uma das suas tarefas pensar a relação das religiões com o meio ambiente, mas, principalmente, responder e refletir as consequências que a economia de mercado, na sua versão mais agressiva, a neoliberal, tem fomentado na cultura contemporânea, como a desvalorização de bens simbólicos do ser humano que o dignifica na sua dimensão cultural e societária, forjando, cada vez mais, uma acirrada corrida consumista, atrelando à existência humana o ato de comprar e lucrar como bens simbólicos por excelência. 
Assim, sabemos que essa terminologia (Teologia das Religiões) procura ser uma chave de leitura, a partir da teologia cristã, que tem como fim proporcionar uma reflexão em tempos de pluralismo religioso (TEIXEIRA, 1995, p. 12). Nesse intento, a teologia das religiões quer ser promotora de uma reflexão em que a teologia cristã, com seu arcabouço teológico, tenha condições sistêmicas para o diálogo com outras expressões religiosas, mas tendo como pré-condição uma revisão de seus pressupostos teológicos para que seja possível uma abertura para o outro que também, assim como o cristianismo enquanto experiência religiosa, possui valores teológicos e pontos comuns que possibilitam o diálogo. Por essa razão, que Claude Geffré (2013, p. 43) sintetiza: "Teologia das religiões se tornou um dos capítulos mais vivos da teologia contemporânea". Ou seja, a primeira tarefa da teologia nesse tempo é produzir uma teologia das religiões que tenha como principal foco o pluralismo religioso. Nessa direção, em alinhar teologia cristã das religiões e pluralismo religioso, está José María Vigil (2006, p. 13), que sentencia: "A teologia das religiões ou do pluralismo religioso é teologia, ou seja, reflexão à luz da fé sobre pluralismo religioso, quer dizer, sobre a pluralidade das religiões, sobre o fato de que a religião não seja uma, senão muitas”. O conceito (teologia das religiões), ao que tudo indica, está condicionado à reflexão que a teologia cristã faz, ou procura fazer, a partir de sua própria concepção teológica, sobre as demais religiões. Nesse sentido é uma teologia cristã das religiões. Um esforço legítimo e necessário. Hoje, o tema da teologia das religiões tem sido amplamente disseminado por diversos autores cristãos que procuram colocar em pauta a necessidade de uma reflexão séria que contemple um status de alteridade em relação às demais religiões, e esse empreendimento tem proporcionado profundas e interessantes contribuições para o debate. Esse trabalho caminha nessa direção.

\section{Teologia das Religiões: a interface protestante}

Devo dizer de novo que uma teologia cristã que não seja capaz de empreender um diálogo criativo com o pensamento teológico das outras religiões perde uma ocasião histórica mundial e permanece provincial

(Paul Tillich) 
No universo protestante, por não ter um filtro centralizador que conduza a reflexão teológica a partir de um polo imbuído de autoridade revelacional como é na Igreja Católica (Tradição/Magistério) - ainda que a Bíblia, no ambiente protestante tenha essa tarefa, e na versão conservadora do protestantismo a tutela revelacional passa pelo literalismo da interpretação histórico-gramatical -, a teologia das religiões caminha de maneira esporádica, a partir de alguns autores. Isso se dá, porque no protestantismo "a fragmentação do mundo protestante e sua individualidade na interpretação das Escrituras impedem que apontemos um teólogo, ou mesmo um concílio, como representantes do pensamento protestante" (PEDREIRA, 1999, p. 75). Para alguns autores, essa fragmentação é um fator negativo para os protestantes, porque assim o protestantismo não teria condições de formular uma reflexão teológica sobre as demais religiões de maneira abrangente e concorde, por não ter um alcance maior nas suas propostas e um centro de fomentação comum. Nesse sentido, a Reforma protestante contribuiu de maneira muito significativa para esse quadro de pluralidade. Mesmo que o mundo protestante tenha promovido encontros missionários e, nesses encontros, o tema das religiões foram veiculados, essas conferências "são proveitosas do ponto de vista social e cultural, mais ainda não fecundas do ponto de vista teológico" (ROUNER, 1986, p. 117). Não havendo um único modo de compreender as religiões, uma única interpretação teológica, um concílio definidor ou documentos reguladores, entendemos que o protestantismo tem condições, por natureza político-teológica, de fomentar propostas em linguagem teológica que contempla o pluralismo religioso, sem, precisamente, ser tutelada por uma instituição eclesiástica ou um código ordinário de controle teológico, mesmo sendo a Bíblia um fator de norma consensual na elaboração teológica - ainda assim a mesma não contempla, de maneira satisfatória e inequívoca, antes com ambiguidades, o tema das religiões. É dentro desse cenário que é possível aventar na produção de uma teologia das religiões em perspectiva protestante, sendo um caminho interessante, dada as circunstâncias do ethos protestante. Assim, conclui, Leroy Rouner (1986, p. 117): "Mais interessante é o esforço de alguns pensadores protestantes, individualmente, no sentido de forjar uma teologia das religiões". 
Nesse sentido, procuramos acolher a reflexão teológica de dois autores que procuraram colocar no seu horizonte o tema das religiões, Paul Tillich e Jürgen Moltmann. Esses teólogos elencados merecem o devido destaque porque, de maneira diretiva, contribuíram para o fortalecimento de uma teologia das religiões. No momento, nos deteremos em dois autores que contribuem para o fortalecimento da teologia das religiões a partir da perspectiva protestante. Paul Tillich, pelo seu contexto histórico, não pode ser identificado como um expoente da teologia das religiões, antes um teólogo da cultura que se ocupou com a história das religiões, intensificando a sua reflexão a partir do encontro que teve com budistas no Japão (1960). Jürgen Moltmann, por colocar como uma das preocupações centrais das religiões as principais questões sociais, convocando as expressões religiosas para compor uma alternativa dentro desse quadro global do atual momento do mundo. Será a partir desses dois autores elencados, que pretendemos indicar uma concepção teológica em que a linguagem seja plausível a partir de um contexto de pluralidade.

\section{Revelação e fé: Paul Tillich}

$\mathrm{Na}$ extensa produção teológica de Paul Tillich, fazendo os devidos recortes, naturalmente, encontramos uma linguagem teológica que contribui para o debate do pluralismo religioso e que não passa, necessariamente, pelas três comumente conhecidas vias da discussão (exclusivista, inclusivista e pluralista). ${ }^{1}$ Isso, certamente, não significa que não seja possível formular uma teologia cristã das religiões a partir do pensamento de Tillich, algo que pesquisadores já formularam. ${ }^{2}$ No nosso caso, optamos por acolher a percepção tillichiana sobre revelação e fé, com seus desdobramentos. É a partir desses dois temas, ainda que abordados de maneira muito suscita, que pretendemos expor uma

1 "De início é preciso compreender que Tillich não foi um teólogo das religiões e nunca elaborou uma teologia do pluralismo religioso. Ele foi principalmente um teólogo sistemático e um teólogo da cultura" (BALEEIRO, 2018, p. 250).

2 Ver: MATHIAS, Luiz Guilherme Kochem. Teologia sistemática e religiões mundiais: aproximações tillichianas ao tema da pluralidade religiosa. (Tese de Doutorado - Programa de Pós-graduação em Ciências da Religião da Universidade Federal de Juiz de Fora/MG). Juiz de Fora: UFJF, 2013. 
linguagem teológica que favoreça, a partir do tema revelação e fé, uma condição para se pensar o pluralismo religioso.

De acordo com Tommy Akira Goto (2004, p. 110), Tillich quando desenvolve o seu principal método, o da correlação, resgata a fenomenologia para investigar o ser. Antes de procurar os fundamentos metafísicos do ser, Tillich procura o fundamento originário do ser, ou seja, não se parte da metafisica para compreender o ser humano, pois ela (a metafísica) já seria um recurso hermenêutico. A fenomenologia está presente na teologia sistemática como instrumento analítico dos conceitos teológicos (GOTO, 2004, p. 124). Um desses conceitos é o da revelação. Ela é analisada fenomenologicamente "porque parte da experiência individual e não de construções especulativas" (GOTO, 2004, p. 126). Para o nosso propósito, frisamos que a manifestação do sagrado como fenômeno (aquilo que aparece à consciência, seguindo Edmund Husserl, filósofo que Tillich compartilha) possibilita, per si, o pluralismo religioso, sendo a manifestação da diversidade religiosa enquanto momento subsequente à dimensão do sagrado. Foquemos no aspecto revelação.

A aproximação de Tillich com o tema da história das religiões sempre foi uma preocupação no seu pensamento e trajetória de vida. Essa preocupação não começou com a sua viagem ao Japão (1960). Ocorre que depois dessa viagem, e em decorrência do diálogo que Tillich teve com budistas, proporcionou à ele uma maior percepção quanto à pluralidade religiosa. Nas suas conferências com o colega Mircea Eliade, na Universidade de Chicago (1965), foi possível Tillich contribuir, ainda mais, como teólogo sistemático, ao debate em torno da teologia das religiões. Depois do seu falecimento, alguns dias após a apresentação de sua conferência, Eliade organiza suas preleções e um importante texto, ainda que curto, nos dá a possibilidade de vislumbrar alguns apontamentos no seu pensando quanto ao desafio das religiões. Trata-se do texto $O$ significado da história das religiões para o teólogo sistemático (1976).

Nessa conferência, Tillich (1976, p. 95-118) trata de duas posturas, igualmente radicais em seu tempo, de teólogos frente às demais religiões. Karl Barth é classificado como um teólogo que rejeita as demais religiões, com exceção da sua própria, e, por outro lado, teólogos que 
postulam uma teologia-sem-Deus, provavelmente uma referência ao movimento teológico conhecido como "teologia da morte de Deus" tendo como principais expoentes William Hamilton e Thomas Altizer, que defendem uma total secularização frente à religião (CALVANI, 2010, p, 154). Uma das conclusões de Tillich é de que "as experiências revelatórias são universalmente humanas. Existe revelação em todas as religiões porque Deus sempre deu testemunho de si mesmo" (CALVANI, 2010, p. 154). No seu pequeno texto, Tillich fornece cinco passos para uma análise da história das religiões e o terceiro procura colocar a fenomenologia como critério de avaliação, ou seja, "o terceiro passo consiste em apresentar uma fenomenologia da religião, mostrando os fenômenos, em especial aqueles que se revelam na história da religião: símbolos, ritos, ideias e diversas atividades" (TILLICH, 1976, p. 116). Tomando a fenomenologia como suporte metodológico, é possível perguntar por algo anterior ao fenômeno religioso. Essa pergunta nos remete ao conceito tillichiano da revelação. Em correlação à revelação há a razão. Como aqui o espaço é limitado para o detalhamento da compreensão tillichiana de razão, importa saber que para ele razão contempla uma dimensão ontológica. Há uma profundidade na razão que possibilita "apontar para a verdade-em-si, isto é, ao poder infinito do ser e do ultimamente real" (TILLICH, 2005, p. 93). Em diversos âmbitos da vida humana, a razão se manifesta principalmente na sua dimensão espiritual. É neste âmbito que a razão pergunta pela revelação. Com todos os dilemas e conflitos aglutinados na razão, a revelação se faz necessária "pois é justamente a revelação que mostra claramente a condição da razão e vem ao encontro das perguntas e anseios que, desde esta condição, ela formula ou expressa" (MUELLER, 2005, p. 62-63). Sendo assim, "a revelação é a manifestação daquilo que nos diz respeito de forma última. O mistério revelado é nossa preocupação última, porque é o fundamento de nosso ser" (TILLICH, 2005, p. 123). Essa ideia focada na história das religiões é elucidativa enquanto manifestação do pluralismo religioso, pois os eventos reveladores sempre foram descritos como acontecimentos que chocam, transformam, exigem; que são significativos de forma última. Eles procedem de fontes divinas, do poder daquilo que é santo e que, portanto, possui uma reivindicação incondicional sobre nós. Só o mistério que é de preocupação última para 
nós aparece na revelação (TILLICH, 2005, p. 123). É essa preocupação última que possibilita o encontro com as religiões: "A revelação última e perfeita do cristianismo pode também ser encontrada nas outras religiões, expressa em outros símbolos" (BALEEIRO, 2018, p. 261). A religião se dá como fenômeno de algo que a precede. Portanto, a religião se dá dentro da dimensão ontológica do ser humano. Com isso, é possível conceber o pluralismo religioso como um fato subsequente da própria condição humana que, nas contradições da razão, pergunta pela revelação sendo essa pergunta ontologicamente possível porque se encontra com a preocupação última do ser humano. "A revelação para Tillich tem um significado bem preciso, identificando-se com aquilo que diz respeito ao ser humano 'de forma última"' (TEIXEIRA, 2012, p. 54). A partir disso, "nenhuma religião pode alimentar a pretensão de ter o monopólio da revelação divina" (TEIXEIRA, 2012, p. 54). É plausível, então, dizer que "Tillich soube identificar com grande delicadeza a presença da universalidade e riqueza dos 'dons' de Deus, que sempre antecedem a dinâmica da busca religiosa realizada pelos seres humanos" (TEIXEIRA, 2012, p. 54).

Na Teologia Sistemática (2005), Tillich pontua os meios pelos quais a revelação pode se manifestar. Dentre eles, ele destaca a natureza, ou seja, os objetos naturais são portadores de revelação (TILLICH, 2005, p. 131). Mesmo a natureza tendo essa condição de ser meio de revelação, Tillich argumenta de que isso não significa uma revelação natural. A teologia natural, como ficou conhecida, também foi alvo de críticas e teve como um dos principais opositores Karl Barth. Para Tillich (2005, p. 132), não pode haver revelação natural, "pois se é conhecimento natural não é revelação, e se é revelação ela torna extática e milagrosa a natureza". A revelação se dá no processo em que a razão levanta a questão do fundamento do ser - conceito chave no sistema teológico tillichiano - mas nem a revelação natural (como consequência a teologia natural) pode dar a resposta, apenas a revelação pode respondê-la (TILLICH, 2005, p. 132). Assim, "a revelação pertence à autocompreensão de toda a religião, que sempre se considera a si mesma criação divina, e não meramente humana" (TORRES QUEIRUGA, 1995, p. 20). Essa sentença coloca a revelação como sendo algo anterior à expressão religiosa, ou seja, "a religião é a tomada de consciência da 
presença do divino no mundo" (TORRES QUEIRUGA, 1995, p. 21). Essa tomada de consciência, em Tillich, é a percepção do mistério último que toca incondicionalmente. Nesse sentido, o reconhecimento do pluralismo religioso, a partir de Tillich, se dá quando a concepção da preocupação última e suprema (Ultimate Concern) passa a ser o critério de encontro entre as religiões (RIBEIRO, 2014, p. 47). Quando esse for o critério, a revelação passa a ser uma consequência ontológica da razão, tornando possível o reconhecimento de que as demais tradições religiosas contemplam em suas manifestações a presença do sagrado. É neste sentido que Geffré (2013, p. 113) tem razão quando diz que "a experiência do sagrado, como experiência da preocupação última, que é o ponto de convergência de todas as religiões".

Um outro aspecto do pensamento tillichiano que destacamos, para que assim possamos contribuir com uma linguagem teológica que abarque o pluralismo religioso, é a fé.

Partindo da assertiva de que "fé é estar possuído por aquilo que nos toca incondicionalmente" (TILLICH, 1985, p. 5), Tillich concebe a fé como algo intrínseco ao ser humano, como uma dimensão primeira deste. Uma realidade que envolve o ser humano e todas as suas características e não apenas uma parte ou função, se é que é possível dividi-lo; ela é mais que uma função ou dimensão humana, ela "ultrapassa cada uma das áreas da vida humana ao mesmo tempo em que se faz sentir em cada uma delas" (TILLICH, 1985, p. 8). Essa fé tem como fonte o incondicional, ou seja, a preocupação última que para Tillich é a "capacidade de transcender o fluxo contínuo de experiências finitas e passageiras" (TILLICH, 1985, p. 10). O incondicional não é necessariamente Deus, mas este pode ser perfeitamente um símbolo do incondicional por ser este (Deus) expresso por meio de uma linguagem simbólica. Deus, nesse caso, seria símbolo de Deus. O incondicional não seria confundido com Deus, por ser, antes, uma leitura posterior no caso aqui do cristianismo -, do incondicional. ${ }^{3}$ Aquilo que Tillich

3 No caso do protestantismo, especificamente, é bom frisar que o "princípio protestante implica uma não absolutização de qualquer expressão de religiosidade - e isso não exclui desta crítica a Igreja cristã! Tillich rompe com o monopólio da revelação de Deus apenas no evento Cristo abrindo possibilidades de revelações preparatórias através da Presença Espiritual" (ABREU, 2008, p. 192). 
chama de preocupação incondicional da fé, se dá em duas dimensões que não se opõem, mas que se complementam: são os aspectos objetivo e subjetivo da fé. O aspecto subjetivo se encontra no "ato de crer" e o aspecto objetivo se encontra no "que se crê" (TILLICH, 1985, p. 11). $\mathrm{O}$ ato de crer é estar possuído por aquilo que nos toca incondicionalmente, mas o destino que se dá para aquilo que toca incondicionalmente passa a ser o objeto de devoção que pode ser a religião, como também a nação, como Tillich costuma exemplificar para desqualificar o regime nazista e outras formas de totalitarismo (TILLICH, 1985, p. 12). É neste sentido então que fé pode se tornar idolátrica. Isso ocorre quando há uma confusão entre o subjetivo e o objetivo. Quando não há uma distinção entre esses dois elementos, a fé se transforma em idolatria. $\mathrm{O}$ aspecto idolátrico da fé, segundo Tillich, é quando coisas passageiras e finitas são colocadas como incondicionais, quando na verdade são condicionadas pelo ambiente vivencial, pela cultura ou pelo dogma. $\mathrm{O}$ perigo de fazer ídolos é corrente. Essa possibilidade acontece quando o objeto que se crê passa a ser o ato de crer, ou seja, quando aquilo que deveria ser símbolo do incondicional tornar-se o absoluto, sendo colocado no lugar do incondicional (TILLICH, 1985, p. 64).

A fé em Tillich se dá na dinâmica da vida. Uma vez sendo ela, a fé, uma realidade do ser humano que não pode ser confundida com o conhecimento, com a vontade e nem mesmo com o sentimento, fé passa a ser o elemento primordial da vida; a responsável por integrar o ser humano à sua preocupação última e por fazê-lo caminhar em direção ao sagrado. Este estar em direção a algo, por si só já qualifica a dinâmica da vida por meio da fé. Essa dinâmica se dá no movimento, no impulso para algo; não pode ser estático, rígido, mas sempre sendo um processo contínuo de fé. Sendo assim, a fé não pode ser enquadrada em códigos definidos, muito menos em concepções dadas a priori, antes é um convite a ser, a fazer, a compreender.

A vida vivida a partir da nomeação do incondicional, carrega suas ambiguidades (TILLICH, 1985, p. 65-68). Nunca é um fato em si concretamente sem a possibilidade de elementos como a dúvida, por exemplo. Além da dúvida, a fé tem na sua dinâmica a coragem, porque esta se arrisca em crer e considera possível o fracasso em se crer. É a partir dessas tensões que a fé pode ser viva, contagiante e um 
descobrir. Viver a partir da fé é estar possuído por aquilo que nos toca incondicionalmente e, ao mesmo tempo, é arriscar-se no direcionamento dessa fé (o que se crê) e isso demanda coragem. A dúvida pensada a partir do dogma é elemento nocivo à fé; é uma temeridade porque a fé não pode conviver com a possibilidade de duvidar. Assim a ausência da dúvida provoca o surgimento de ídolos. A dúvida que Tillich pontua, como parte inseparável da fé, não se dá em torno de fatos ou consequências lógicas (TILLICH, 1985, p. 17). A dúvida é elemento que favorece a fé, pois sem esta não haveria a coragem que encara o risco da fé (TILLICH, 1985, p. 18).

A fé para ser verbalizada necessita de uma linguagem. A linguagem é extremamente necessária, do contrário não haveria conteúdo para a fé. A questão é a construção da linguagem de fé, não uma linguagem que encerra em si mesma a condição de dizer tudo sobre o sentido último, mas que possa dar pistas para um descobrir e vivenciar. Por essa razão, que uma linguagem teológica precisa ser simbólica, uma vez que "os símbolos são aquilo por meio dos quais as religiões expressam o incondicional universal presente nas suas experiências revelatórias" (BALEEIRO, 2018, p. 261). Para Tillich (1985, p. 30), portanto, a "linguagem simbólica consegue expressar o incondicional". Para ele símbolos "indicam algo que se encontra fora deles" (TILLICH, 1985, p. 31). A linguagem simbólica permite um pertencimento naquilo que ela indica, pois desta maneira ela nos remete a níveis de realidade tornando acessível a realidade do incondicional. O símbolo carrega em si a máxima possibilidade que o ser humano tem em exprimir a linguagem da fé (HIGUET, 2012, p. 89). Neste sentido não seriam as proposições teológicas a única maneira de expressar o conteúdo da fé, antes "a linguagem da fé é a linguagem simbólica. A fé enquanto fato de ser tomado por uma preocupação absoluta não possui outra linguagem" (HIGUET, 2012, p. 89). É por essa razão, que "a linguagem da teologia ou das religiões são linguagens essencialmente simbólicas" (HIGUET, 2012, p. 89). O símbolo tem a capacidade de colocar diante de nós a realidade que ele representa (HIGUET, 2012, p. 89). Neste sentido Deus passa a ser símbolo de Deus, ou seja, quando atribuímos a ele amor, justiça, bondade e cuidado (TILLICH, 1985, p. 34). Essa linguagem é possível porque Deus passa a ser símbolo daquilo que nos 
toca incondicionalmente; ele passa a ser o conteúdo da fé, mas com o seu respectivo risco.

Em Tillich, temos uma linguagem teológica que pensa a revelação, um tema tão fundamental para a teologia cristã, não a partir de um núcleo duro e enrijecido pelo dogma. Em Tillich encontramos uma linguagem teológica em que há uma distinção entre a preocupação última e as formas concretas dessa preocupação, ou seja, há uma "distinção entre a essência da revelação e sua forma concreta e histórica" (RIBEIRO, 2014, p. 51). Com a percepção de que a revelação, ainda que Tillich não relativize a figura de Cristo, fazendo uma distinção entre o Cristo $(\operatorname{Logos})$ a sua manifestação histórica em Jesus, ${ }^{4}$ não é algo circunscrito ao cristianismo, antes é um fenômeno que toca incondicionalmente, e tem na fé uma manifestação do incondicional. Aqui temos uma linguagem teológica em Tillich que contribui, de maneira significativa - uma vez considerando o seu momento histórico, bem como o seu reconhecido destaque na teologia contemporânea -, para que tenhamos uma concepção de que as religiões, dentro da sua dimensão histórica, abriga a manifestação do Absoluto e que colhe, como todas as expressões religiosas, fragmentos dessa manifestação através da revelação. ${ }^{5}$ Assim, o pluralismo religioso pode ser lido a partir de uma linguagem teológica que não absolutiza nenhuma manifestação religiosa na história, nem mesmo trata a fé, e suas mediações simbólicas, como um fim em si mesma.

\section{Religiões e promoção da vida: Jürgen Moltmann}

Assim como Tillich, o teólogo alemão Jürgen Moltmann tem uma extensa produção bibliográfica. Conhecido como o "teólogo da esperança" a partir da década de 1960, Moltmann ganhou um destacado espaço na reflexão teológico quando procurou pensar a escatologia teológica com a filosofia da esperança do filósofo Ernst Bloch.

\footnotetext{
4 “O evento de Jesus enquanto Cristo é um símbolo cristão que aponta para algo que está presente em outras religiões" (BALEEIRO, 2018, p. 262).

5 "Tillich indicou que a base religiosa universal é a experiência do Santo dentro do finito. O Santo, como realidade teológica e espiritual fundamental, surge nas coisas finitas e particulares, tanto nas concretas como nas universais [...]. A experiência do Santo, como vivência do Ultimate Concern, é a convergência de todas as religiões e permite um critério comum para o diálogo inter-religioso" (RIBEIRO, 2010, p. 58).
} 
Gostaríamos de destacar a contribuição desse renomado teólogo para o tema das religiões, realçando uma linguagem teológica que procura articular as tradições religiosas na suas dimensões teológica e ética, com os desafios que são prementes no mundo. É bom deixar claro que Moltmann não procura se enquadrar nos modelos ou paradigmas (exclusivista, inclusivista, pluralista) quanto à teologia das religiões. Ainda assim, Moltmann (2000, p. 250) não se omite em emitir a sua opinião quanto a realidade do pluralismo religioso: "O pluralismo [...] não é uma teoria metarreligiosa de inter-relação de tradições religiosas, mas sim aceitação patente da realidade de outras comunidades religiosas, da coexistência com elas". Não obstante a esse reconhecimento, Moltmann não se recusa a fazer algumas considerações quanto ao status do pluralismo que ele julga está em vigor, pelo menos em alguns contextos: "Diferentes tradições religiosas perdem sua capacidade de serem os elementos de união das sociedades e, em lugar disso, se convertem em meras opções para que os consumidores religiosos selecionem segundo seus motivos privados, motivos que não são discutidos" (MOLTMANN, 2000, p. 251). A crítica do autor se dá a partir de um pluralismo que relativiza as tradições religiosas, colocando-as como produtos a serem consumidas sem, necessariamente, a devida atenção para o potencial de construção social como fomentadoras de temas da sociedade. Para Moltmann (2000, p. 251), "as religiões entram no mercado como objetos de eleição subjetiva, do mesmo modo que marcas de pasta de dente ou detergente para a louça”. A crítica de Moltmann, portanto, ao pluralismo religioso não se dá no seu reconhecimento, antes a sua crítica está concentrada na relativização das religiões, colocadas no mercado religioso como uma opção para uma sociedade marcada pelo consumo (MOLTMANN, 2000, p. 251). Nesse sentido, o pluralismo religioso não pode ser apenas aceitável, mas também indesejável, porque contribui para ampliar as possibilidades subjetivas, enquanto reprime "a possibilidade de que os símbolos religiosos medeiem uma realidade objetiva” (MOLTMANN, 2000, p. 251). Em outras palavras, "o pluralismo religioso passou a ser tolerado, aceito e valorizado na medida em que a religião deixou de ser o fundamento ideológico da ordem social, quando ela deixou de ser importante para a manutenção da ordem social" (SUNG, 2016, p. 196). A postura de Moltmann (2000, 
p. 251), diante do relativismo que possa estar presente no pluralismo religioso, é rejeitar uma atuação "para perpetuar a tolerância e o pluralismo em todo o mundo, enquanto condena todas as pretensões absolutas das tradições religiosas". É nesse sentido que Moltmann pontua a relevância da participação das tradições religiosas, uma vez admitindo a pluralidade religiosa, para que, dentro de suas respectivas percepções, contribua com assuntos comuns que atingem a todos, por isso a importância do diálogo entre as religiões.

O eixo no qual Moltmann gira, se dá a partir das preocupações em torno de temas comuns ao ser humano e suas necessidades vitais, como sua sobrevivência (natureza), como também o convívio social (direitos humanos). Nesse sentido, o teólogo católico Geffré compartilha da mesma perspectiva que Moltmann. Ambos têm procurado colocar o tema do diálogo inter-religioso dentro de um contexto onde as preocupações humanas sejam valorizadas. Essa preocupação está presente em grandes organismos como o Parlamento Mundial das Religiões e a Conferência Mundial das Religiões para a Paz. ${ }^{6}$ Organismos que procuram ser "um lugar de confronto e de diálogo das principais religiões do mundo a serviço da paz, da promoção dos direitos humanos e da preservação da natureza" (GEFFRÉ, 2013, p. 14). A discussão teológica entre as religiões tem o seu lugar, mas para Geffré a "aproximação das religiões entre si é profundamente coerente com nossa experiência histórica neste início do século XXI" (GEFFRÉ, 2013, p. 14). Um século que apresenta enormes desafios diante de problemas reais para o ser humano e sua dignidade, mas tendem a serem minimizados por setores que controlam a economia na já consagrada globalização. Ainda que o debate teológico seja relevante, por se tratar da transcendência, da revelação e da salvação, a dimensão ética também se apresenta como indispensável a partir do pluralismo religioso, uma vez que "todas as religiões devem ter em conta a ética dos direitos humanos e estar dispostas a reinterpretarem seus textos fundadores, suas tradições doutrinais e jurídicas

\footnotetext{
6 "Já existe uma ética nos ensinamentos religiosos, capaz de oferecer orientação diversa à esses desdobramentos globais funestos. Embora essa ética não ofereça soluções diretas para todos os imensos problemas mundiais, oferece a base moral para uma ordem individual e global melhor: uma visão capaz de afastar homens e mulheres do desespero, e as sociedades, do caos" (KÜNG; SCHMIDT, 2001, p. 15).
} 
em função de nossa nova experiência histórica" (GEFFRÉ, 2013, p. 15). É dentro dessa perspectiva, ou seja, favorecer um encontro entre as religiões onde preocupações emergentes do ser humano seja uma pauta prioritária, que trazemos a linguagem teológica de Moltmann.

Há dois temas que perpassam as religiões na contemporaneidade: a paz e a violência. No 11 de setembro de 2001, o mundo contemporâneo conheceu a força devastadora do que chamamos, comumente, de fundamentalismo religioso. Depois desse trágico dia, o mundo vem, cada vez mais, tomando conhecimento do quanto a religião pode ser prejudicial ao ser humano, principalmente depois dos ataques à Paris em 2015. O mundo aprendeu a entender quais são os principais alvos dos temidos jihadistas, que não apenas agem, mas pregam uma luta, a partir da violência, como necessária para a restauração da vontade de Allah. Não apenas o islã, como também o judaísmo e o cristianismo, carregam um histórico de violência, assim como as demais tradições religiosas no Oriente também. Por isso a paz é um tema igualmente fundamental, e as religiões são recipientes naturais de uma mensagem de paz, pelo menos deveria ser.

Foi Hans Küng (2003, p. 7) quem popularizou a frase "não haverá paz no mundo sem paz entre as religiões. E sem paz entre as religiões não haverá diálogo entre as religiões". A paz consistiu um importante elo entre as religiões. Com ela, as religiões podem visualizar os principais desafios do ser humano, o que não ocorre quando há guerras e intolerância. Faustino Teixeira (2014, p. 101), nos lembra que "a violência religiosa não faz parte da essência da religião, mas constitui um desvio ou traição do dinamismo mais profundo que anima a relação do ser humano com o mistério Absoluto". Um caminho de paz abre um caminho para a justiça.

A justiça está presente na trajetória das religiões, principalmente as monoteístas. Na tradição bíblica, a justiça está na pregação profética, há um Deus/Javé de justiça. É Tillich (1974, p. 179) quem aponta a justiça como um dos critérios para se julgar as religiões, inclusive o próprio cristianismo: "A justiça é um princípio que transcende a todas as religiões particulares e atribui um caráter condicional a exclusividade de qualquer uma delas". No cristianismo, Jesus ensinou que os homens são aceitos pela justiça praticada, e não necessariamente pela religião 
confessada. Nesse sentido, segundo Tillich (1974, p. 175), falando sobre as três religiões proféticas, judaísmo, islamismo e cristianismo, elas "possuem como essência - apesar do seu secularismo, seu nacionalismo e a injustiça organizada - a busca profética da justiça".

As religiões têm força ética para promover mudanças. O Estado, comprometido com o mercado, ignora a grande maioria das pessoas que lutam pela sobrevivência. É neste sentido que as religiões podem contribuir. "A dor do mundo e o sofrimento dos pobres e excluídos traduzem um novo desafio para as religiões e apontam para um novo kairós hermenêutico para o encontro das religiões: dialogar para não deixar morrer" (TEIXEIRA, 2014, p. 101). As religiões não podem abrir mão de sua participação e atuação no atual contexto humano. Momento em que o mundo conhece o drama da imigração na Europa; a intolerância religiosa e o terror do estado islâmico; a brutalidade contra minorias que buscam seus direitos, como o atentando à boate Pulse, na Flórida (EUA) em 2016; a luta por direitos de populações negras no Brasil. Todos esses e muitos outros, são temas que as religiões não podem se furtar. Mesmo porque, a justiça não é o principal foco do Estado. Em uma sociedade onde se depende, exclusivamente, da justiça legal, acentua-se muito mais a sua desumanidade. Assim, a sociedade ainda deve dar lugar "aos valores pregados pelas religiões, como a compaixão, o perdão, a atenção prioritária aos mais necessitados" (GEFFRÉ, 2013, p. 15). A justiça precisa ser um critério entre as religiões. A justiça, impulsionada pelas religiões, tem condições para assumir uma função instrumental de equidade nas relações humanas, como também promover uma justiça comprometida com a sobrevivência e manutenção da natureza. O critério para se avaliar uma religião, se dá na medida em que ela serve à humanidade. Se ela não "promove a identidade humana, o sentido e sentimento de valor das pessoas" (KÜNG, 2003, p. 147), ela favorece a desumanização. Se aceitarmos o fato de que "as grandes questões que afetam a humanidade e toda a criação requerem, por suposto, indicações teológicas consistentes" (RIBEIRO, 2014, p. 57), uma vez que são grandes e desafiadores os temas como a paz e a justiça, "são necessários eixos norteadores para que a reflexão teológica possua uma abrangência capaz de ser relevante diante dos desafios que a sociedade apresenta" (RIBEIRO, 2014, p. 57). Uma reflexão teológica 
engajada nesse contexto, pode contribuir para caminhos de paz e justiça. É nesse sentido que Moltmann procura articular suas concepções teológicas no atual momento do mundo.

Moltmann (2008, p. 35) faz o mesmo apelo por paz entre as religiões, uma vez que "não sopra atualmente um vento de paz". O pressuposto fundamental para as religiões é a paz, porque somente a partir dela será possível concentrar forças em temas comuns ao mundo: "Se as religiões mundiais quiserem realmente servir à vida do mundo, elas mesmas precisam primeiro ser capazes de viver a paz" (MOLTMANN, 2008, p. 35-36). É aqui que Moltmann (2012, p. 195) alude a um critério para as religiões quando entende que "a paz consiste politicamente na presença da justiça, não apenas na ausência de violência”. Ele lembra que o Deus bíblico promove a justiça e estabelece o direito. É um Deus que liberta escravos; faz justiça aos órfãos e viúvas e se faz presente junto aos abandonados e perdidos (MOLTMANN, 2007, p. 81). O Deus bíblico se dá na prática da justiça e onde há injustiça, a sua ação é libertadora: "Deus também já está presente lá onde acontece a injustiça. Fazendo justiça aos que sofrem violência. O que é feito aos pobres e indefesos indiretamente é também feito a ele" (MOLTMANN, 2007, p. 82). Os profetas reivindicam justiça diante dos desmandos do Estado. Há uma luta intensa pelo direito dos despossuídos, desfavorecidos e marginalizados da sociedade. Moltmann não concebe uma justiça vingativa, onde os "maus" sofrem e os "bons" são bem-aventurados. A justiça, pela perspectiva bíblica, se dá no direito, ou seja, "a justiça de Deus é, ao mesmo tempo, aquela que cria o direito, mas também traz justiça à vida injustiçada. Desta forma, é uma justiça criativa. Deus faz justiça a quem sofre violência e põe em ordem quem comete o mal" (MOLTMANN, 2008, p. 72).

Moltmann faz uma reflexão em torno desse tema justiça em um texto que tem como título Ética da esperança (2012). Essas preocupações perpassam todo o texto e a justiça ganha o seu devido destaque, juntamente com o tema da paz. Isso se dá, porque "somente a justiça assegura a paz" (MOLTMANN, 2012, p. 196). O autor faz um importante debate envolvendo diferentes abordagens, mas também as religiões, nosso interesse aqui. Ele faz uma crítica a segmentos dentro das religiões que não promovem a paz, mas, pelo contrário, fomentam o 
ódio e a intolerância. Nesse sentido, Moltmann lembra alguns episódios como os ataques do 11 de setembro de 2001 e o pronunciamento dos fundamentalistas assegurando o "castigo divino aplicado à Nova York 'homossexual', como se Deus fosse um Deus dos terroristas" (MOLTMANN, 2012, p. 201). Ele lembra também de casos como o tsunami na Indonésia que ocorreu em 2004, em que fundamentalistas atribuíram a catástrofe como castigo divino pelo país ter um islã muito tolerante. Essas posturas não contribuem para a promoção da paz, muito menos para a justiça. Há um clamor por justiça, principalmente por aqueles que são vítimas da violência. Tanto o cristianismo, o judaísmo quanto o islamismo, em suas ambiguidades, tem condições para promover caminhos de justiça. O judaísmo, como já mencionado, conhece um Deus de justiça, que luta pelos menos favorecidos. O cristianismo tem em Jesus o seu maior exemplo, de alguém que "se aplica aos doentes, não aos saudáveis; sua amizade abraçou os marginalizados, pecadores e coletores de impostos; ele estava com os perdidos, não com os bons" (MOLTMANN, 2012, p. 214). No islamismo, a própria raiz da palavra islam tem como derivação a palavra salam (paz). Em seu universo semântico, islam inclui conciliação e pacificação (ROCHA PINTO, 2010, p. 42). Um dos cinco pilares da fé no islã é a zakat - que não se encontra correspondente em português podendo ser traduzido como caridade. É um ensinamento expresso de doação e cuidado para com os pobres (ARANTES, 2008, p. 34). A concepção de justiça também está presente no islã, como em toda religião profética, desde o início com o profeta Maomé. Com o profeta, “os árabes foram elevados ao plano de uma grande religião ética, fundamentada na fé no Deus único e em um etos básico da humanidade, com claros imperativos de mais humanitarismo e mais justiça” (KÜNG, 2004, p. 264). Moltmann (2016, p. 105) lembra, que "a misericórdia e a compaixão são louvadas em todas as religiões mundiais. Nesse sentido pode-se falar de um ecumenismo da comunidade religiosa, que deve tornar mais fecundo o seu diálogo em vista do sofrimento no mundo".

A busca por justiça se dá em torno dos direitos humanos, econômico e ecológico. Os problemas que afetam a todos, como os danos ao meio ambiente, e os conflitos sociais e econômicos, serão mediados pela justiça. A justiça seria o meio pela qual as religiões buscariam 
consenso na luta pelos "direitos humanos e os direitos da natureza" (MOLTMANN, 2012, p. 255). Esse caminho traz importantes contribuições, mas também é consciente de que essa tarefa se dá "em nível religioso explícito ou não, em formas institucionais ou de caráter mais espontâneo" (RIBEIRO, 2016, p. 22). Essa busca por justiça, nem sempre encontra ressonância, as vezes é um caminho penoso que só vale a pena por um ideal de justiça. As tensões pelas quais o mundo passa como o fanatismo, o racismo e o terrorismo, as religiões não podem se furtarem. O atual cenário, que pode ser considerado pessimista, não dá sinais de melhoras quando os principais articuladores da condição humana é o Estado, a ciência e o sistema econômico. Acertadamente, Geffré (2013, p. 24) nos lembra de que

no momento em que o mundo contemporâneo está sob o signo da crescente dominação do técnico-econômico que ameaça o futuro do genoma humano e viola os direitos da terra, é vocação permanente das grandes tradições religiosas da humanidade serem instâncias de sabedoria que lembram que o homem não se define somente pela luta pelo lucro, pela manipulação da natureza e da vida.

Uma vez as religiões podendo articular ações concretas em torno da paz, a busca pela justiça será uma contribuição salutar para o mundo.

\section{Considerações finais}

A fim de demonstrar a importância das tradições religiosas para a teologia protestante e de como uma linguagem teológica é plausível dentro do contexto de pluralismo religioso, olhamos para dois teólogos de reconhecido destaque na teologia contemporânea, Paul Tillich e Jürgen Moltmann. Os dois são diferentes quanto à métodos e abordagens teológicas. Tillich contribui para pensar a revelação em suas diferentes manifestações, não apenas no cristianismo. Sua abordagem ao tema se dá em relação a razão e a fé; e sua linguagem passa pelo símbolo como principal elemento de discurso hermenêutico-teológico. Moltmann, não tem, até o momento, uma teologia das religiões. Ainda assim, o autor se dedica ao tema em diversos textos, emitindo a sua opinião sobre a temática, mas também procurando contribuir com uma linguagem teológica que dialogue com o contexto de pluralismo religioso, como 
o autor reconhece ser o nosso atual momento no seu sentido positivo, ainda que critique duramente as tentativas de relativização das tradições religiosas e a constante investida para marginalizar as religiões do drama social. É aqui que Moltmann chama as religiões para a conversa, sendo que são elas a nutrirem um discurso que não se enquadra com as demandas do sistema capitalista; com a degradação do meio ambiente; com a intolerância às minorias; com a ausência de direitos básicos de sobrevivência. A linguagem teológica das religiões, portanto, passa pela noção de justiça e paz.

\section{Referências}

ABREU, Fábio Henrique P. de. "Vencendo o exclusivismo: notas de algumas contribuições da teologia de Paul Tillich para a teologia das religiões". Sacrilegens, vol. 5, n. 1, p. 175-197, 2008.

ARANTES, José Tadeu. O maior perigo do islã - não conhecê-lo. São Paulo: Terceiro Nome, 2008.

BALEEIRO, Cleber. "Tillich e a teologia do pluralismo religioso". In: TADA, Elton Sadao; SOUZA, Vítor Chaves de (Orgs.). Paul Tillich e a linguagem da religião. São Paulo: Kapenke, 2018, p. 249-263.

CALVANI, Carlos Eduardo B. Teologia da arte: espiritualidade, igreja e cultura a partir de Paul Tillich. São Paulo: Fonte Editorial/Paulinas, 2010.

GEFFRÉ, Claude. De Babel a Pentecostes: ensaios de teologia inter-religiosa. São Paulo: Paulus, 2013.

HIGUET, Etienne A. "Interpretação das imagens na teologia e nas ciências da religião". In: NOGUEIRA, Paulo A. de Souza (Org.). Linguagens da religião: desafios, métodos e conceitos centrais. São Paulo: Paulinas, 2012, p. 69-106.

KNITTER, Paul F. Introdução às teologias das religiões. São Paulo: Paulinas, 2008.

KÜNG, Hans. Projeto de ética mundial: uma moral ecumênica em vista da sobrevivência humana. 4. ed. São Paulo: Paulinas, 2003.

KÜNG, Hans. Religiões do mundo: em busca dos pontos comuns. Campinas: Verus, 2004.

KÜNG, Hans; SCHMIDT, Helmut. Uma ética mundial e responsabilidades globais: duas declarações. São Paulo: Loyola, 2001.

MATHIAS, Luiz Guilherme Kochem. Teologia sistemática e religiões mundiais: aproximações tillichianas ao tema da pluralidade religiosa. (Tese de Doutorado - Programa de Pós-graduação em Ciências da Religião da Universidade Federal de Juiz de Fora/MG). Juiz de Fora: UFJF, 2013. 
MOLTMANN, Jürgen. "Es la 'teología pluralista' útil para el diálogo de las religiones del mundo?". In: D'COSTA, Gavin (Ed.). La unicidade Cristiana reconsiderada: el mito de una teología pluralista de las religiones. Bilbao: Desclée de Brouwer, 2000, p. 247-257.

MOLTMANN, Jürgen. "Misericórdia e solidariedade". In: BASTOS, Levy da Costa; MOLTMANN, Jürgen. Um cristianismo de futuro: possibilidades missionárias para as igrejas hoje. São Bernardo do Campo: EDITEO, 2016, p. 101-111.

MOLTMANN, Jürgen. Ética da esperança. Petrópolis: Vozes, 2012.

MOLTMANN, Jürgen. No fim, o início: breve tratado sobre a esperança. São Paulo: Loyola, 2007.

MOLTMANN, Jürgen. Vida, esperança e justiça: um testemunho teológico para a América Latina. São Bernardo do Campo: EDITEO, 2008.

MUELLER, Ênio R. "Caminhos do pensar”. In: MUELLER, Ênio R.; BEIMS, Robert W. (Orgs.). Fronteiras e interfaces: o pensamento de Paul Tillich em perspectiva interdisciplinar. São Leopoldo: Sinodal, 2005, p. 41-65.

PEDREIRA, Eduardo Rosa. Do confronto ao encontro: uma análise do cristianismo em suas posições ante os desafios do diálogo inter-religiosa. São Paulo: Paulinas, 1999.

RIBEIRO, Claudio de Oliveira. Pluralismo e libertação. São Paulo: Paulinas, 2014.

RIBEIRO, Claudio de Oliveira. Pode a fé tornar-se idolatria?: a atualidade para a América Latina da relação entre reino de Deus e história em Paul Tillich. Rio de Janeiro: Mauad X/Instituto Mysterium, 2010.

RIBEIRO, Claudio de Oliveira. Religião, democracia e direitos humanos: presença pública inter-religiosa no fortalecimento da democracia e na defesa dos direitos humanos no Brasil. São Paulo: Reflexão, 2016.

ROCHA PINTO, Paulo Gabriel Hilu. Islã - religião e civilização: uma abordagem antropológica. Aparecida: Santuário, 2010.

ROUNER, Leroy. "A teologia das religiões na teologia protestante recente". Concilium, n. 203, 1986/1, p. 115-123.

SUNG, Jung Mo. "Cristianismo como religião pública, pluralismo e diálogo". In: BARRETO JÚNIOR, Raimundo; CAVALCANTE, Ronaldo; ROSA, Wanderley Pereira da (Orgs.). Cristianismo mundial como religião pública. Vitória: UNIDA, 2016, p. 187-201.

TEIXEIRA, Faustino. Cristianismo e diálogo inter-religioso. São Paulo: Fonte Editorial, 2014. 
TEIXEIRA, Faustino. Teologia das religiões: uma visão panorâmica. São Paulo: Paulinas, 1995.

TEIXEIRA, Faustino. Teologia e pluralismo religioso. São Bernardo do Campo: Nhanduti, 2012.

TILLICH, Paul. Dinâmica da fé. 4. ed. São Leopoldo: Sinodal, 1985.

TILLICH, Paul. El futuro de las religiones: cuatro ensayos. Buenos Aires: La Aurora, 1976.

TILLICH, Paul. Teología de la cultura y otros ensayos. Buenos Aires: Amorrortu, 1974.

TILLICH, Paul. Teologia sistemática. 5. ed. São Leopoldo: Sinodal, 2005.

TORRES QUEIRUGA, Andrés. A revelação de Deus na realização humana. São Paulo: Paulus, 1995.

VIGIL, José María. Teologia do pluralismo religioso: para uma releitura pluralista do cristianismo. São Paulo: Paulus, 2006. 